\title{
ROLE OF PHRASEOLOGY IN DEVELOPING COMMUNICATIVE COMPETENCE
}

\author{
Z.J. Sarsenbaeva ${ }^{1}$ \\ ${ }^{1}$ Department of Foreign languages, \\ Nukus state pedagogical institute, \\ Nukus, Uzbekistan, \\ Karakalpakstan,
}

\author{
T.T. Utebaev ${ }^{2}$ \\ ${ }^{2}$ Department of Pedagogy and Psychology of \\ Primary Education, \\ Nukus state pedagogical institute, \\ Nukus, Uzbekistan, \\ Karakalpakstan,
}

Article DOI: https://doi.org/10.36713/epra5111

\begin{abstract}
This article provides information on the effectiveness of improving communicative competence in the teaching process and discusses some ways to develop it. Cultural awareness promotes important ties between culture and language learning encourage teachers of foreign languages. In order to be bilingual and competitive, a non-native learner has to be bicultural. The article investigates some main aspects and principles of communication explicitly and implicitly underline the importance of cultural studies at English as a foreign language classes in the Karakalpak auditoriums. The article depicts the system of values characteristic to a nation can be introduced to learners through proverbs. The methods of descriptive, comparative and logical-semantic analyses are used in the research. The article analyzes the examples that are based on phraseological units, mainly proverbs in Karakalpak in comparison with English proverbs. Communicative competence is considered to be important in order to understand communication ethics, and to improve cultural awareness skills, to develop critical thinking as well. Also, the authors conclude that cultural codes could be a subject of practical study during English as a foreign language, along with other exercises on grammar and speaking skills that could be used by a Karakalpak ESP (English as a specific purpose) teacher.
\end{abstract}

KEY WORDS: Competence, communication, proverb, idiom, culture, phraseology, teaching EFL (English as a foreign language).

\section{INTRODUCTION}

Currently much attention is being increased on methods of teaching and learning English language by focusing on the relation between language, history and culture in modern scientific studies. The term "language competence" refers to both linguistic and communicative competences. According to Thomas (1987), teachers' role is important in order to help their learners gain language competence. In educating qualified English teachers, first of all, emphasis should be put on developing their communicative competence. In order to fulfill this task, teachers should themselves have language competence to a greater degree than that expected of their learners, as well as language awareness that involves explicit knowledge of the language system and how it operates in communication and pedagogic competence that is related to the teaching of language (Thomas 1987, 34). Also, Cross says that subject competence that is the level of English essential for effective language teaching is one of the main components of an ideal teacher profile that the initial teacher education programmes should be based on and, this competence should be attained before trainees enter teacher education institution so that training can focus on the teaching of English and related issues without being sidetracked by language weaknesses (Cross 1995, 3).

In the case of Uzbekistan, Karakalpakstan students before entering higher educational institutions acquire foreign languages at schools and secondary special educations, and they carry on studying English as a foreign language as well as major to gain subject competence to be able to proceed with their professional career.

\section{OBJECTIVES}

Though education programs in higher education institutions and universities include courses that aim to develop student-teachers' language competence, these programs mainly aim to develop pedagogic competence. In spite of the changes, the language related courses might not be sufficient to assist learners overcome their language 
problems; therefore, it is likely that future teachers may fall behind in meeting their language needs if they do not make extra efforts.

Today, the curriculum in many parts of the world encourages communicative approach in spite of the fact that teachers' lack of communicative competence does not allow them to put these approaches into practice. On this problem, (Cullen 1994, 162) asserts that increasing acceptance around the world of the principles of communicative language teaching, there is arguably more pressure on teachers than in the past to be fluent in English so that they can use it naturally and spontaneously in the classroom. According to Wright, it is impossible to speak, read or listen to English without meeting idiomatic language. This is not something you can leave until you reach an advanced level. All native speaker English is idiomatic (Wright 2002, 9). Also, Ellis states that one of the most efficient ways of helping students to overcome their language related problems is to teach them formulaic and figurative expressions such as proverbs, idioms, metaphors, phrasal verbs which are considered to be a crucial part of natural language production (Ellis, 2008).

Proverbs are not given a special place in the literature concerning language teaching despite the advantages they could bring into the language auditoriums. Proverbs as part conventional fixed expressions could make speech fluent, natural and colourful, can allow to perform certain communicative functions and increase students' understanding and cultural awareness of the target language. Without the knowledge of idiomatic expressions most students may have problems that can result in communication difficulties.

Phraseology, which is the study of phrases, is an umbrella term for the study of all phrasal collocations including the field of paremiology that is the study of proverbs (Mieder 2004). Although paremiologists study proverbs in a more inclusive and comprehensive way with reference to anthropology, art, communication, culture, folklore, history, literature, philology, psychology, religion and sociology, it is in the field of phraseology that linguists have analysed the grammar, structure, syntax, and form of proverbs. Therefore, phraseology deals with all formulaic language or phraseological units from proverbs to literary quotations, from proverbial expressions to idioms, from greeting formulas to phrasal superstitions (Mieder 2004, 133). In addition Cowie (1994) defines phraseology in a general sense as the study of the structure, meaning, and use of word combinations. Idioms and proverbs are the core of phraseology although recent corpusbased approaches include a wide range of word combinations which are largely compositional unlike idiomatic expressions (Granger, Paquot, 2008).

\section{METHODOLOGY}

Although there have been many definitions of proverbs, a broad definition is provided by Mieder. He states: A proverb is a short, generally known sentence of the folk which contains wisdom, truth, morals, and traditional views in a metaphorical, fixed and a form which is easy to memorize and is handed down across generations (Mieder 2004, 3). According to the characteristics of proverbs reflected in the definition above, proverbs are significant rhetorical force in various modes of communication used by native speakers not only in friendly conversations but also in best seller novels and the influential mass media. Significance and usefulness of proverbs in communication and in language classrooms are further explained from various aspects as in the following:

1) As part of cultural references, proverbs are traditional and a part of cultural literacy, experiences, values, history and thoughts of a nation and therefore, study of proverbs can contribute to the development of cultural and intercultural competence by enabling learners to gain insights into how native speakers conceptualize experiences, by making comparisons in their language (Bessmertnyi 1994; Ciccarelli 1996; Richmond 1987);

2) Figurative language, many proverbs are metaphorical and contain prosodic devices (D'Angelo 1977; Mieder 2004; Norrick 1985; Ridout, Witting 1969) and hence, can be used to prompt figurative thinking and enhance metaphoric competence;

3) Functional language, proverbs are used to carry out many communicative functions particularly indirect speech act as a politeness strategy (Norrick 2007), and are employed in text organization. The flexibility of proverbs also allows playing with their language and generating anti-proverbs which can be used to create humour, irony and jokes (Litovkina, Mieder, 2006; Mieder, 2004). Therefore, teaching the pragmatic aspects of proverbs in context can contribute to the improvement of pragmatic competence (Charteris Black 1995);

4) Formulaic language, use of proverbs can enable fluent and natural language production and hence, teaching of proverbs can help to produce language more fluently and naturally which can in turn increase motivation (Porto 1998); Although nonnative speakers or language learners avoid using idiomatic expressions and prefer literal and direct language items (O'Keeffe, McCarthy, Carter, 2007), avoiding the use of idioms gives language a stilted, unimaginative tone (Cooper 1999, 258), which underlines the importance of learning idiomatic expressions to accomplish command of authentic language.

5) Knowledge of proverbs as part of idiomatic expressions can increase comprehension of texts and 
using them can make learners' verbal and written communication more effective (Irujo, 1986);

6) Proverbs are considered to be practical tools to teach vocabulary, exemplify grammar points, to show creative use of language, and to teach pronunciation due to their musical quality (Nuessel, 2003).

Most importantly, knowledge of proverbs can enable them to have access to native speakers' culture and cognition, hence, help them approach language learning and teaching in a more meaningful way. As Nuessel $(2003,158)$ states that proverbs and the metaphors contained in them comprise a microcosm of what it means to know a second language since these expressions require both the knowledge of linguistic structure and the sociolinguistic and discourse factors involved in recognizing and using them appropriately.

Furthermore, Litovkina (2000) summarizes the obstacles language learners may face due to their lack of knowledge of proverbs and states that the person who does not acquire competence in using proverbs will be limited in conversation, will have difficulty comprehending a wide variety of printed matter, radio, television, songs and will not understand proverb parodies which presuppose a familiarity with a stock proverb. In most cases, native speakers usually play with the language of proverbs to create humour, which could only be made sense of if the proverb is known to the hearer or the reader. In rare cases, learners can make use of their knowledge in their first language to comprehend a proverb resulting in positive transfer but they are not always lucky enough to achieve this particularly with proverbs that are different both syntactically and semantically across the two languages. The studies on the processing of idioms and proverbs reveal negative transfer from the first language particularly in comprehending similar idioms-idioms that are semantically the same but syntactically different (Boers, Demecheleer, 2001; Irujo, 1986).

We assume that using phraseological units in the language, and idiomatic speech will help students to develop not only communicative competences, but also linguocultural competence, and to improve fluency in a foreign language as well. Because of these reasons, proverbs cannot be learned without explicit instruction in the classroom in English as a foreign language setting such as Karakalpakstan since there is limited exposure to English outside classroom even though access to English speaking channels on TV, internet and other means of mass media has increased. Therefore, Irujo $(1984,122)$ puts forward that television and movies do not allow for opportunities to clarify meaning and receive feedback on use, which are essential for acquisition. In this case, explicit instruction on idiomatic expressions is essential for future EFL (English as a foreign language) teachers who can then provide instruction on these expressions for their students more confidently. Phraseology has much to offer for the development of communicative competence. As well as language competence, students and teachers should have language awareness to be competent language teachers because they are going to teach not only in the target language but also about the target language. Thornbury (1997) states that language awareness as the knowledge that teachers have of the underlying systems of language that enables them to teach effectively. The advantages language awareness can bring are that language teachers can anticipate students' difficulties with certain aspects of language, (Thornbury, 1997), prepare lessons, evaluate and adapt materials, evaluate and design a syllabus and check students' performance more effectively and confidently (Wright, Bolitho, 1993).

Furthermore, when learners come up with a language learning problem, teachers with language awareness can better guide these learners and provide explanations about the language (Bartels, 2005). This suggests that in training language teachers, research findings in linguistics and applied linguistics should be incorporated in materials and lessons as much as possible so as to increase awareness. This ability, in turn, will contribute directly to effective teaching (Andrews, 2007). As the most important source of input for language learners, language teachers need to know about the target language and culture. The different features present in different proverbs make them various, which has resulted in the formation of many definitions. So, the variety in proverbs makes it difficult to come up with a definition that encompasses all the features of proverbs and that enables one to identify them easily.

However, in relation to Barley's method, Norrick $(2007,382)$ identifies the fuzziness of the category and the scalar application of features in defining such culturally determined items as he argues that no single proverb can include all the characteristics that are thought to be prototypical. For instance, one of the prototypical features of proverbs is that proverbs evoke a scenario that is general to many similar situations such as The early bird gets the worm - Erte turg'annin' irisqisi ko'p bolar; $A$ stitch in time saves nine - Bu'gingi isti erten'ge qaldirma. In contrast to this, there are proverbs that make use of literal statements such as: Like father, like son - A'kege qaray ul o'ser; One man's meat is is another man's poison - Qassapshig'a et qayg'i, qara eshkige jan qayg'i; Better late than never Heshten ko're kesh jaqsi.

Moreover, there are even those proverbs which are specific to a particular topic and thus, are not general to many situations and these proverbs are said to use figurative language in a less striking way like: Money talks - Ga'pin'nen pulin' jaqsi; Time flies - Waqit ag'ip turg'an da'rya siyaqli; Beauty's 
only skin deep - Suliwinan jiliwi. In addition, Milner (1971) and Dundes (1975) take a structural approach to define proverbs. Milner (1971) identified the quadripartite structure of proverbs. Based on this structure, proverbs such as: $A$ rolling stone gathers no moss - Jatqang'a jan juwimaydi; Qiymildag'an qir asar, can be divided into four parts with either positive or negative values assigned to each of the four elements which in turn creates sixteen possible structural patterns (Milner, 1971).

However, Mieder (2004) does not find this sufficient to define a proverb since sentences such as Who buys the beer, determines the party and A running chicken collects no flowers have a quadripartite structure but they are not proverbs (Mieder, 2004). As well as Milner, Dundes (1975) adopts a structural approach and defines a proverb as a propositional statement consisting of at least a topic and a comment as in Money talks; Time flies. This means that a proverb must be composed of at least two words (Mieder, 2004). However, with regard to this, Mieder (2004) again illustrates that not every statement with such a structure is a proverb by showing the example Politicians decide, soldiers fight which is not a proverb despite its oppositional structure. Therefore, it is seen that the structural definitions are not satisfactory to enable us to identify a proverb.

\section{RESULTS}

Proverbs are usually classified as the subcategory of idioms for instance by McCarthy and O'Dell (2002) and the differences between the two are often discussed based on their formal aspects. They are both said to be traditional and to have a fixed form and a literary value but the sentence structure of proverbs make them different from idioms (Harnish, 1993). Most idioms are constituted in the form of phrases such as noun phrases, verb phrases and prepositional phrases (Dobrovol'skij, Piirainen, 2005). In other words, sentential patterns are usually excluded from the category of idioms; however, a phraseme like the coast is clear is not a proverb but an idiom despite its sentence structure which shows that sentence idioms and proverbs can be differentiated based on not only syntax but also semantics and pragmatics.

An important remark is made by Dobrovol'skij and Piirainen (2005) and Ridout and Witting (1969) regarding how closely proverbs and idioms are related to each other. Based on the example to cry for the moon, Ridout and Witting (1969) demonstrate that even though the idiom which gives no advice and warning is not a proverb it can easily be transformed into a proverb by changing its form into a form of advice as in Don't cry for the moon or Only fools cry for the moon. Other examples of idioms that are or can be turned into proverbs are: Do not halloo till you are out of the wood - Suwdi ko'rmey etik sheshpe; A skeleton in the cupboard - Ha'r kimnin' o'z haqiyqati boladi. Similarly, Dobrovol'skij and Piirainen (2005) discuss that the phrases in proverbs can become the origin of many idioms. For example, the last straw is the reduced form of the proverb: It is the last straw that breaks the camel's back - Son'g'i pushayman o'zin'e dushpan but is used as an idiom. Dobrovol'skij and Piirainen (2005) further indicated that a lexical item can be used both as an idiom and as a proverb as in the examples: When the cat is away, the mice will play - Iyt joqta shoshqa u'rer (proverb) and We ought to do a bit of work this afternoon even though the cat's away (idiom). Therefore, proverbs are not idioms but they are idiomatic expressions and thus, closely connected to idioms.

Not only the figurative proverbs but also the literal proverbs (Actions speak louder than words Insan $o^{\prime} z$ miyneti menen belgili) are culturallyoriented as they all emerge out of the experiences of a specific society. Therefore, learning proverbs could show how native speakers conceptualize experiences, things and events in their language.

Thus, proverbs as the cultural heritage of native speakers are significant to preserve the culture and to facilitate the perception and understanding of the world for the new generation (Hidasi, 2008, 103). Therefore, the relation between proverb and culture is interconnected and cannot be disregarded.

\section{DISCUSSION}

The cultural aspect of proverbs has important implications for developing learners' cultural and intercultural competence. In the language teaching profession, it has been recognized that mastering the grammar of a foreign language in isolation from the cultural context is not enough sufficient in order to be communicatively competent. In this case, this has led to the emergence of communicative approaches. However, it is said that these approaches have not been successful enough to bring out culturally competent language learners. As for language classrooms where there is an attempt to incorporate culture teaching, the problem is that teachers usually know how to teach culture but they do not know what to teach regarding the culture (Morain, 1983). As Bennett points that the teaching of little which includes learned and shared patterns of beliefs, behaviour and values of groups of interacting people is more likely to develop cultural competence (Bennett 1998, 2).

Regarding this, Peterson, Coltrane $(2003,1)$ assert that the culture associated with a language cannot be learned in a few lessons about celebrations, folk songs, or costumes of the area in which the language is spoken. About the Intercultural Communicative Competence (ICC), Lundgren (2004) makes a clear distinction among communicative competence, cultural competence and intercultural 
competence and argues that the integration of the three components that can result in the achievement of ICC. Therefore, in our presumption, ICC requires the development of these three competences. According to Lundgren, while communicative competence involves the ability to communicate in four language skills with sensitivity to genres, cultural competence involves the knowledge of everyday culture, popular culture, ideas, beliefs, perceptions, behaviour, literature, art, class, and intercultural competence involves a cross curricular general proficiency including adaptability, tolerance, accepting other views, empathy, flexibility, cultural awareness along with the knowledge of the concepts such as ethnocentricity, stereotyping, and social constructivism (Lundgren 2004, 2).

1. What is earned with hard labor is eaten with pleasure - Miynet etsen' erinbey toyadi qarnin' tilenbey.

2. With hard work, you can get fire out of a stone - Miynet tu'bi ra'hat.

3. Lazy people want much but get little, but those who work hard will prosper - Miyneti azdin' miywasi az.

4. Work hard and become a leader; be lazy and become a slave - Qiymildag'an qir asra, Bu'lkildegen jer teser; Isti bilip isle, aqildi qosip isle.

5. Hard work always pays off; but mere talk puts no bread on the table - Ha'rekette bereket bar; Ju'rgen ozar, turg'an tozar.

6. Those who work their land will have abundant food, but those who chase fantasies have no sense - Miynetin kim ko'rse ra'hati de sol ko'redi.

7. Good planning and hard work lead to prosperity, but hasty shortcuts lead to poverty - Jaqsi islesen' asin'di jersen', Jaman islesen' basin'di jersen'.

8. Lend your money and lose your friend Qariz qatnasiqti buzadi.

9. Money doesn't grow on trees - Bayliq jerden sipirip alinbaydi. shaqiradi

10. Money makes money - Aqshani aqsha

11. Money cannot buy happiness - Baxit bayliqqa satip alinbaydi.

The teacher can get students to match both the English and Karakalpak proverbs with the definitions given so that students can realize that some of the proverbs in English and Turkish have similar meanings and that some of the proverbs within the same culture share similar definitions. In addition, in the teaching process, the learners can be asked to mark the proverbs which have positive meanings about a specific theme and those which have negative meanings. In this way, they can be made to see that even the proverbs in one language can contradict each other. In this phase, one of the most important steps is to get students to compare the proverbs
Overall, the goals of ICC as stated by Byram, Gribkova, and Starkey $(2002,6)$ are: to give learners intercultural competence as well as linguistic competence; to prepare them for interaction with people of other cultures; accept people from other cultures as individuals with other distinctive perspectives, values and behaviour; to help them see that such interaction can be an enriching experience. For this reason, the aim on the part of language learners is not to become native speakers but to become intercultural speakers, who act as mediators between two cultures, interprets and understands other perspectives as well as to be have fluency in that language. In the following, corpus of English and Karakalpak Proverbs on hard work and money. English Proverbs with Karakalpak definitions:

across the two cultures. This could be effectively carried out by using the model of target and native language proverb and phraseological units comparison proposed by Richmond (1987) so that students' ability to analyse cultures through language and hence, to figure out how differently the two cultures can express similar meanings could be enhanced.

Proverbs and sayings reflect moral values widely accepted in the society and contain widely used and accepted evaluations of human behavior and actions in various situations and in different circumstances. Proverbs can be used in teaching some national and culture oriented linguistic data at foreign language classes. The knowledge of proverbs of the studied language can lead to better understanding of culture and national identity. Various exercises on grammar, vocabulary and phonetics can be applied by a teacher of the Karakalpak language at different stages of the education process.

\section{CONCLUSION}

According to their didactic significance proverbs vividly represent the system of values of a nation. We cannot state that the images and metaphors are unique and specific only to Karakalpak or English culture, but they are very typical for these cultures and are reduplicated in other forms of folklore, such as folk songs, fairytales, riddles, thus being an integral part of the folk oral heritage, as the same national unity see the world and perceive the world through stereotypes. It is important to note that during individuals' speech the verbal experience is developed which involves a certain subjective conceptualization of hierarchy and structure of speech elements. To master grammatical and lexical material students may be given exercises with gaps, for example: Fill in the gap: Atag'a qaray $-\ldots$, Anag'a qaray -.... The teacher can apply the communicative method in teaching grammatical forms: pronouns, degrees of comparison of 
adjectives, imperative forms, and modal verbs interacting with students. To develop students' speaking skills teachers can offer monologue exercises. Students could illustrate proverbs basing on their life experience, telling short stories. Telling a story illustrating the proverb: A'kege qaray ul o'ser, anag'a qaray qiz o'ser (Like father, like son). To develop students' speaking skills teachers can offer dialogue exercises. Students could discuss the meaning of the proverbs with their partners: (Atan'a ne qilsan' aldin'a sol keler). To develop students' speaking skills teachers can offer answering and asking the following questions to their partners: How important is it to obey parents?/Are you going to follow your parents' footsteps in a career choice?/Can you name some famous professional dynasties?/Why do some children choose the same profession as their parents?, and others. Students speak on the topic of family values developing speaking abilities, and acquire knowledge about Karakalpak culture. Communicative exercises in the lessons increase students' motivation and interest in learning the language. All these exercises can promote formation, development and improvement of sociocultural competence of students as well as teach the cultural codes as the proverbs reflect a historical, cultural context. A linguistic approach enables to learn cultural codes of the nation and make the communication in the studied language more effective. Students speak on various topics and acquire knowledge about Karakalpak culture. Communicative exercises in the lessons increase students' motivation and interest in learning the language.

Thus, proverbs in English language teaching need to be further studied from various perspectives. It will be invaluable to study the following topics regarding proverbs: English language teachers' attitudes towards teaching proverbs and their practice in teaching process; empirical studies on the effectiveness of proverbs in developing language learners' cultural and pragmatic competences; proverb teaching to students of different levels of language proficiency; cross-cultural studies on the semantic, cultural, literary and pragmatic aspects of proverbs and phraseological units to provide input for classroom instruction.

\section{REFERENCES}

1. Andrews, S. (2007): Teacher language awareness. Cambridge: Cambridge University Press.

2. Bartels, N. (2005): Applied Linguistics and Language Teacher Education: What We Know. In N. Bartels (Ed.), Applied Linguistics and Language Teacher Education. pp. 405-425. Boston: Springer.

3. Bennett, M. J. (1998). Intercultural communication: A current perspective. In M. J. Bennett (Ed.), Basic concepts of intercultural communication: A reader (pp. 1-34). Yarmouth, ME: Intercultural Press.

4. Bessmertnyi, A. (1994): Teaching cultural literacy to foreign-language students. English Teaching Forum, 32(4), 24-27.

5. Boers, F., Demecheleer, M. (2001): Measuring the impact of cross-cultural differences on learners' comprehension of imageable idioms. ELT Journal, 55(3), 255-262.

6. Can, N. (2011): Killing two birds with one stone: Proverbs and intercultural communicative competence. Proceedings of the $10^{\text {th }}$ International Language, Literature and Stylistics Symposium, Gazi University, Ankara.

7. Charteris-Black, J. (1995): Proverbs in communication. Journal of Multilingual Multicultural Development, 16, 259-268.

8. Ciccarelli, A. (1996): Teaching culture through language: Suggestions for the Italian language class. Italica, 73(4), 563-576.

9. Cowie, A. P. (1994): Phraseology. In R. E.Asher (Ed.). The encyclopedia of language and linguistics pp. 3168-3171. Oxford: Oxford University Press.

10. Cooper, T. C. (1999): Processing of idioms by L2 learners of English. TESOL Quarterly, 33(2), 233262.

11. Cross, D. (1995): Language teacher preparation in developing countries: Structuring preservice teacher training programs. English Teaching Forum, 6, 34-36.

12. Cullen, R. (1994): Incorporating a language improvement component in teacher training programmes. ELT Journal, 48(2), 162-172.

13. D'Angelo, F. J. (1977): Some uses of proverbs. College Composition and Communication, 28(4), 365-369.

14. Dobrovol'skij, D., Piirainen, E. (2005): Figurative language: Cross-cultural and cross-linguistic perspectives. Oxford: Elsevier.

15. Dundes, Alan. (1994): Slurs international. Folk comparisons of ethnicity and national character. In Wolfgang Mieder (Ed.), Wise Words. Essays on the Proverb. New York: Garland Publishing Inc., 183-209.

16. Ellis, N. C. (2008): Phraseology: The periphery and the heart of language. In F. Meunier., S. Granger (Eds.), Phraseology in foreign language learning and teaching. pp. 1-15, Amsterdam: John Benjamins Publishing Company.

17. Granger, S., Paquot, M. (2008): Disentangling the phraseological web. In S. Granger., F. Meunier (Eds.), Phraseology: An interdisciplinary perspective, pp. 27-51, Amsterdam: John Benjamins Publishing.

18. Harnish, R. M. (1993): Communicating with proverbs. Communication and Cognition, 26(3/4), 265-290.

19. Hidasi, J. (2008): Cultural messages of metaphors. In E. A Berendt (Ed.), Metaphors for learning: Cross-cultural perspectives, pp. 103123. Amsterdam: John Benjamins Publishing.

20. Holden, M. H., Warshaw, M. (1985): A bird in the hand and a bird in the bush: Using proverbs to 
teach skills and comprehension. The English Journal, 74(2), 63-67.

21. Irujo, S. (1986): Don 't put your leg in your mouth: Transfer in the acquisition of idioms in a second language. TESOL Quarterly, 20(2), 287-304.

22. Litovkina, A. T., Mieder, W. (2006): Old proverbs never die, they just diversify. Hungary: University of Veszprem Press.

23. Lundgren, U. (2004): An intercultural approach to foreign language teaching. Retrieved November 8, 2009, from http://tntee.umu.se.

24. Mieder, W. (2004): Proverbs - A Handbook. Westport, CT; Greenwood Press.

25. Mieder, W. (2007): Proverbs as cultural units or items of folklore. In H. Burger, D. Dobrovol'skij, P. Kühn \& N. R. Norrick (Eds.), Phraseology: An international handbook of contemporary research, pp. 394- 414, Berlin, Germany: Walter de Gruyter.

26. Milner, G. (1971): The quartered shield: Outline of a semantic taxonomy. In E. Ardener (Ed.), Social anthropology and language, pp. 243-269. London: Tavistock.

27. Morain, G. (1983): Commitment to the teaching of foreign cultures. The Modern Language Journal, 67(4), 403-412.

28. Norrick, N. R. (2007): Proverbs as set phrases. In H. Burger, D. Dobrovol'skij, P. Kühn, N. R. Norrick (Eds.), Phraseology: An international handbook of contemporary research, pp. 381-394. Berlin, Germany: Walter de Gruyter.

29. Nuessel, F. (2003): Proverbs and metaphoric language in second-language acquisition. In W. Mieder (Ed.), Cognition, comprehension and communication. A decade of North American proverb studies, pp. 395-412. Hohengehren: Schneider-Verlag.

30. O'Keeffe, A., McCarthy, M., Carter, R. (2007): From corpus to classroom: Language use and language teaching. Cambridge: Cambridge University Press.

31. Peterson, E., Coltrane, B. (2003): Culture in second language teaching. ERIC Digest.

32. Piirainen, E. (2007): Phrasemes from a cultural semiotic perspective. In $H$. Burger, $D$. Dobrovol'skij, P. Kühn., N. R. Norrick (Eds.), Phraseology: An international handbook of contemporary research, pp. 208-220. Berlin, Germany: Walter de Gruyter.

33. Piirainen, E. (2008): Figurative phraseology and culture. In S. Granger \& F. Meunier (Eds.), Phraseology: An interdisciplinary perspective, $p p$. 207- 229. Amsterdam: John Benjamins Publishing.

34. Porto, M. (1998): Lexical phrases and language teaching. Forum 36(3). Retrieved from http://exchanges.state.gov/forum/vols/vol36/no3/p 22.htm

35. Richmond, E. B. (1987): Utilizing proverbs as a focal point to cultural awareness and communicative competence: Illustrations from Africa. Foreign Language Annals, 20(3), 213-216.

36. Ridout, R., Witting, C. (1969): English proverbs explained. Cavaye Place, London: Pan Books.
37. Thornbury, S. (1997): About language. Cambridge: Cambridge University Press.

38. Thomas, A. (1987): Language teacher competence and language teacher education. In $R$. Bowers (Ed.), Language teacher education: An integrated programme for ELT teacher training, pp. 33-42. London: British Council, Modern English Publications.

39. Wright, T., Bolitho, R. (1993): Language awareness: A missing link in language teacher education? ELT Journal, 47(4), 292-304.

40. Wright, J. (2002): Idioms organizer: Organized by metaphor, topic and keyword. Boston: Thomson, Heinle.

41. Byram, M., Gribkova, B. Starkey, H. (2002): Developing the intercultural dimension in language teaching. A practical introduction for teachers. Strasbourg: Council of Europe. 